\title{
EFEKTIVITAS PEMBELAJARAN KOOPERATIF (COOPERATIVE LEARNING) UNTUK MENINGKATKAN KETERAMPILAN SOSIAL PADA SISWA TAMAN KANAK-KANAK
}

\author{
Dian Rachmawati Wasito ${ }^{1}$ \\ Herdina Indrijati \\ Fakultas Psikologi \\ Universitas Airlangga Surabaya \\ Jalan Airlangga No.4-6, Surabaya \\ Jawa Timur 60286, Indonesia \\ 'e-mail: dian.rachmawati24@gmail.com
}

\begin{abstract}
The present study was conducted to determine whether cooperative learning can improve students' social skills in kindergarten effectively. Cooperative learning includes two techniques, think-pair-share and jigsaw, which were conducted within 10 days. Subjects in the present study amounts to 10 students obtained based on the lower scale by parents and teachers. Results showed that there were differences in social skills of the subjects pre-and post-study. The present study showed that cooperative learning techniques think-pair-share and jigsaw can improve social skills of kindergarten students in the aspects of cooperation, assertiveness, and self-control.
\end{abstract}

Keywords: kindergarten students; social skills; cooperative learning

\begin{abstract}
Abstrak - Penelitian dilakukan untuk mengetahui apakah pembelajaran kooperatif efektif untuk meningkatkan keterampilan sosial pada siswa taman kanak-kanak. Pembelajaran kooperatif yang digunakan dalam penelitian ini dua teknik yaitu teknik think-pair-share dan jigsaw yang dilaksanakan dalam waktu 10 hari. Subjek dalam penelitian berjumlah 10 siswa yang diperoleh berdasarkan hasil skala rendah oleh orangtua dan guru. Hasil penelitian menunjukkan bahwa ada perbedaan keterampilan sosial pada subjek penelitian pada saat sebelum dan sesudah penelitian. Dalam penelitian ini diperoleh bahwa pembelajaran kooperatif teknik think-pair-share dan jigsaw dapat meningkatkan keterampilan sosial siswa taman kanak-kanak baik pada aspek kerjasama, asertif, dan kontrol diri.
\end{abstract}

Kata kunci: siswa taman kanak-kanak; keterampilan sosial; pembelajaran kooperatif 


\section{PENDAHULUAN}

Departemen Pendidikan Nasional (2003) menjelaskan bahwa fungsi pendidikan taman kanak-kanak adalah mengenalkan peraturan dan mencanangkan disiplin anak, mengenalkan anak dengan dunia sekitar, menumbuhkan sikap dan perilaku yang baik, mengembangkan kemampuan dan bersosialisasi, mengembangkan keterampilan, kreativitas dan kemampuan yang dimiliki anak, serta menyiapkan anak untuk memasuki pendidikan dasar.

Sehubungan dengan adanya fungsi hal tersebut maka dapat diperoleh bahwa salah satu fungsi dari pendidikan taman kanak-kanak ialah sebagai tempat anak belajar menjadi pribadi yang dapat diterima oleh lingkungan sekitarnya dengan cara mampu berperilaku baik dan mampu bersosialisasi dengan lingkungannya. Pendidikan taman kanak-kanak juga akan menjadi tempat untuk mempelajari keterampilan sosial.

Keterampilan sosial merupakan proses pembelajaran perilaku sosial yang memungkinkan seseorang untuk berinteraksi dengan orang lain dengan cara memberikan respon positif dan menghindari respon negatif (Elliot \& Busse, 1991). Keterampilan ini dibutuhkan setiap orang untuk dapat diterima oleh lingkungannya. Keterampilan sosial sebaiknya diajarkan sejak dini mengingat perkembangan sosial anak mulai berkembang sejak masa kanak-kanak awal.

Anak prasekolah perlu memiliki keterampilan sosial. Hal ini dianggap perlu karena anak akan bertemu dengan guru dan teman saat berada di lingkungan sekolahnya. Sehubungan dengan adanya hal tersebut, maka anak prasekolah diharapkan dapat berinteraksi dengan cara memberikan respon positif dan berperilaku yang baik saat berada di lingkungannya.

Di Indonesia, keterampilan sosial kurang dikembangkan dalam proses belajar mengajar di taman kanak-kanak. Adapun hasil penelitian oleh Izzaty dan tim yang menunjang pernyataan di atas yaitu ditemukan pemahaman pendidik TK dalam kajian keterampilan sosial sangat minimal dan beberapa bentuk program yang ada dilakukan dengan tidak sadar atau terprogram dengan jelas (Izzaty, Cholimah, \& Hayati, n.d.).

Penelitian lain yang menunjang menyebutkan bahwa hasil survei terhadap 35 taman kanak-kanak di Yogyakarta tahun 2008 berkenaan dengan pemecahan masalah sosial anak bahwa strategi penyelesaian permasalahan yang jumlahnya paling banyak yang dilakukan 
anak-anak pada saat melakukan interaksi adalah strategi yang cenderung negatif atau bersifat agresi, seperti memukul, menendang, menjambak, dan mencubit (Setiawati, n.d.).

Adapun hasil wawancara yang menunjang hasil penelitian di atas. Penulis juga telah melakukan wawancara kepada salah satu guru TK X di Surabaya pada tanggal 9 Oktober 2014. Hasil wawancara tersebut diperoleh bahwa dalam mengembangkan keterampilan sosial siswa, guru hanya memberikan peraturan sebelum proses belajar dan hal tersebut kurang memberikan hasil secara maksimal. Keadaan kelas setelah diberikan instruksi menjadi tenang tetapi setelah beberapa waktu akan kembali gaduh atau terjadi pertengkaran di dalam kelas. Hasil wawancara guru di atas menjelaskan bahwa guru berusaha untuk memberikan proses belajar keterampilan sosial melalui program pembelajaran namun kurang terstruktur dengan jelas sehingga hasil juga kurang maksimal. Hal tersebut menjadi sebuah masalah karena guru berperan besar dalam mengenalkan dan mengembangkan keterampilan sosial bagi siswanya

Dalam penelitian early childhood longitudinal study - TK cohort (ECLS-K) menyebutkan bahwa efek guru pada keterampilan sosial dan perilaku cukup besar. Hal ini terjadi karena guru yang dapat mengajarkan keterampilan sosial dan perilaku yang baik di kelas SD awal maka secara tidak langsung dapat meningkatkan keterampilan akademik (Jennings \& Diprete, 2009). Terdapat juga pendapat bahwa keterampilan sosial merupakan faktor yang sangat penting dalam perkembangan anak (Kibtiyah, 2006). Hal ini menjadi sebuah permasalahan karena keadaan pendidikan taman kanak-kanak di Indonesia kurang mengembangkan keterampilan di sekolah.

Coie (dalam Mukhtar \& Hadhan, 2006) menambahkan bahwa anak dengan keterampilan rendah juga kurang dalam mengontrol emosi, sulit memahami perasaan dan keinginan orang lain, dan kurang terampil dalam menyelesaikan masalah-masalah sosial. Menurut Mutadin (dalam Pujiani, Soedirman, \& Purnomoso, 2011), proses pembentukan keterampilan sosial tidak lepas dari pengaruh keluarga, sekolah, dan masyarakat. Berkaitan dengan pernyataan di atas, ketika orangtua tidak mampu mengajarkan keterampilan sosial dengan baik di rumah, sekolah dapat membantu untuk memberikan proses pembelajaran.

Sehubungan dengan adanya permasalahan terkait dengan rendahnya keterampilan sosial anak prasekolah maka dibutuhkan intervensi sebagai bentuk penanganan di kelas. Dalam sebuah penelitian yang dilakukan oleh Dollman, Morgan, Pergler, Russell, dan Watt (2007), diperoleh bahwa pembelajaran kooperatif dapat menjadi suatu alternatif intervensi untuk meningkatkan keterampilan sosial. Dalam proyek penelitian tindakan yang dilakukan 
oleh Dollman, dkk. menggunakan pembelajaran kooperatif untuk mengembangkan lingkungan kelas yang positif yang kondusif untuk belajar. Dalam penelitiannya, peneliti mengajarkan guru untuk meningkatkan keterampilan sosial siswa melalui strategi roleplaying, jigsaw, think-pair-share, dan penyelenggara grafis.

Pembelajaran kooperatif dapat diterapkan dalam konteks siswa taman kanak-kanak. Hal ini ditunjukkan melalui hasil penelitian yang dilakukan oleh Artut (2009). Hasil penelitian oleh Artut menunjukkan bahwa pembelajaran kooperatif dapat mengembangkan kemampuan matematika taman kanak-kanak serta meningkatkan keterampilan sosial sederhana yaitu anak-anak harus belajar dengan mendengarkan secara aktif, senang berbicara, dan semua siswa harus menjadi peserta aktif. Penelitian ini juga menggunakan teknik jigsaw dengan kurikulum sekolah yang disesuaikan dengan pembelajaran kooperatif.

Sehubungan dengan adanya kebutuhan dalam upaya pengenalan dan peningkatan keterampilan sosial pada anak taman kanak-kanak, maka penulis mencoba untuk menerapkan pembelajaran kooperatif atau cooperative learning pada siswa taman kanak-kanak. Pembelajaran kooperatif yang digunakan dalam penelitian ini menggunakan teknik jigsaw dan think-pair-share. Hal ini dilakukan karena kedua teknik tersebut pernah dilakukan oleh penelitian sebelumnya pada konteks taman kanak-kanak dan dapat meningkatkan keterampilan sosial.

\section{Taman Kanak-kanak}

Taman kanak-kanak adalah salah satu bentuk satuan pendidikan anak usia dini pada jalur pendidikan formal yang menyelenggarakan program pendidikan bagi anak usia 4 tahun sampai 6 tahun (Departemen Pendidikan Nasional, 2004). Dalam peraturan pemerintah nomor 27 tahun 1990 pada bab 1, taman kanak-kanak adalah salah satu pendidikan prasekolah yang menyediakan program pendidikan dini bagi anak usia 4 sampai 6 tahun sebelum memasuki pendidikan dasar (Departemen Pendidikan Nasional, 2003).

\section{Keterampilan sosial}

Menurut Gresham dan Elliot (dalam Elliot \& Busse, 1991), keterampilan sosial dapat didefinisikan sebagai proses belajar perilaku yang dapat diterima secara sosial yang memungkinkan seseorang untuk berinteraksi dengan orang lain dengan cara-cara yang menimbulkan respon positif dan membantu menghindari respon negatif. 


\section{Aspek Keterampilan sosial}

Menurut Gresham (dalam Elliot \& Busse, 1991) keterampilan sosial dapat dibagi dalam lima hal yaitu: (1) Kerja sama (cooperation), perilaku seperti membantu orang lain, berbagi bahan dengan rekan dan mematuhi aturan; (2) Sikap tegas (assertion), memulai perilaku seperti meminta orang lain untuk informasi dan perilaku yang merupakan respons untuk tindakan lain seperti menanggapi tekanan teman sebaya; (3) Tanggung jawab (responsibility), perilaku yang menunjukkan kemampuan untuk berkomunikasi dengan orang dewasa dan keprihatinan mengenai properti seseorang; (4) Empati (empathy), perilaku yang menunjukkan kepedulian terhadap perasaan dewasa pada kelompok; dan (5) Kontrol diri (self control), perilaku yang muncul dalam situasi konflik seperti merespon dengan tepat untuk menggoda atau umpan balik korektif dari orang dewasa.

Menurut Elliott (dalam Frey, Elliot, \& Gresham, 2011), keterampilan sosial yang penting untuk anak-anak prasekolah meliputi mendengarkan orang lain, mengikuti peraturan kelas, mengikuti arahan, meminta bantuan, bekerja sama dengan rekan-rekan, dan mengendalikan emosi pada konflik situasi. Elliot menambahkan bahwa seringkali anak-anak prasekolah yang mengalami kesulitan dalam sekolah memiliki tantangan perilaku sosial namun para peneliti ingin meneliti hubungan antara keterampilan sosial, prestasi akademik, hasil perkembangan akhir, sosial pemecahan masalah, dan keterampilan manajemen diri. Sehubungan dengan adanya hal tersebut, Gresham dan Elliot (dalam Frey, dkk., 2011) membuat Social Skill Rating Scale Preschool Version yang bertujuan untuk mengidentifikasi social skill pada anak dan menentukan intervensi yang tepat terkait dengan perilaku sosial. Social Skill Rating Scale Preschool Version diberikan pada guru dan orangtua. Pada guru meliputi aspek kerja sama, asertif, dan kontrol diri. Sedangkan untuk orangtua meliputi empat aspek yaitu aspek kerja sama, asertif, kontrol diri, dan tanggung jawab.

Dalam hal ini, peneliti menggunakan aspek keterampilan sosial yang disesuaikan dengan alat ukur yang digunakan Gresham dan Elliot (dalam Frey, dkk., 2011), yaitu yang meliputi empat aspek yaitu aspek kerja sama, asertif, kontrol diri, dan tanggung jawab. Keempat aspek tersebut diambil sesuai dengan alat ukur yang telah ada yaitu Social Skill Rating Scale Preschool Version. 


\section{Pengaruh Keterampilan Sosial Bagi Anak}

Dishion (dalam Pujiani, dkk., 2011) menjelaskan bahwa lemahnya keterampilan sosial pada seorang anak dapat menyebabkan kesulitan dalam menyesuaikan diri dengan lingkungan sekitar, sehingga menjadi rendah diri, dikucilkan dari pergaulan, cenderung berperilaku kurang normatif (anti sosial) bahkan dapat lebih ekstrim misalnya gangguan jiwa, kenakalan remaja, kriminal, dan kekerasan. Gresham (Frey, dkk., 2011) menjelaskan kompetensi sosial dengan rekan-rekan di prasekolah dan TK memiliki keterkaitan dengan penyesuaian akademik dan sosial di sekolah dasar. Keterampilan sosial membantu anak-anak menjadi lebih sukses dalam pengaturan akademik.

\section{Asesmen Keterampilan Sosial}

Greenwood, dkk. (dalam Gresham, 1981) menjelaskan mengenai penilaian keterampilan sosial pada anak-anak dan menemukan tiga langkah yang paling umum, yaitu (1) pengamatan perilaku, (2) tindakan sociometric, dan (3) skala guru. Ketiga langkah tersebut juga telah digunakan untuk menilai keterampilan sosial anak agresif atau anak-anak mengganggu dan anak-anak yang memiliki defisit dalam komunikasi atau keterampilan berbicara.

\section{Intervensi untuk Mengembangkan Keterampilan Sosial}

Intervensi keterampilan sosial fokus pada perilaku positif dan menggunakan metode non-aversif seperti pemodelan, pelatihan, dan penguatan untuk memperbaiki perilaku anakanak. Intervensi keterampilan sosial untuk anak yaitu prosedur intervensi operan, pembelajaran kooperatif, prosedur intervensi pembelajaran sosial, dan prosedur intervensi kognitif-perilaku (Elliot \& Busse, 1991).

Upaya untuk meningkatkan keterampilan sosial dapat dilakukan dengan beberapa cara dan salah satunya adalah pembelajaran kooperatif cooperative learning. Menurut Coie (dalam Gillies \& Ashman, 2003), pembelajaran kooperatif pada awal masa kanak-kanak dapat mengembangkan sikap positif terhadap lingkungan sekolah dan teman sebaya. Selain itu, pembelajaran kooperatif dapat memberikan banyak peluang untuk belajar bagaimana dipikirkan orang lain, untuk mengembangkan kemampuan berbahasa, dan belajar bagaimana memecahkan masalah interpersonal. Anak-anak yang belajar berinteraksi dengan sukses dengan rekan-rekan mereka selama prasekolah dan SD tahun awal cenderung diterima 
dengan baik oleh rekan-rekannya sepanjang karier sekolah, sementara anak-anak yang gagal untuk belajar keterampilan ini di kelas-kelas awal cenderung ditolak oleh teman sekelas mereka sepanjang karier sekolah mereka.

\section{Pembelajaran Kooperatif}

Elliot dan Busse (1991) menjelaskan bahwa pembelajaran kooperatif merupakan teknik pembelajaran yang menuntut siswa untuk bekerja sama dalam menyelesaikan tugas akademik. Siswa bekerja dengan kelompok dan bukan individu untuk menyelesaikan tugas akademik. Prosedur ini mengharuskan siswa bekerja sama, berbagi dan saling membantu dalam menyelesaikan tugas dan dengan demikian, merupakan teknik yang efektif untuk meningkatkan kemungkinan perilaku sosial yang positif.

Menurut Bremer (dalam Dollman, dkk., 2007) menjelaskan bahwa think-pair-share, jigsaw, role play, dan penggunaan grafik merupakan strategi pembelajaran kooperatif untuk membantu dengan instruksi dari keterampilan sosial yang tepat. Siegel (dalam Dollman, dkk., 2007) juga menjelaskan bahwa para peneliti telah menganjurkan pelaksanaan dan penggunaan pembelajaran kooperatif strategi jigsaw dan think-pair-share serta penggunaan mind map dapat meningkatkan prestasi siswa dan pengembangan keterampilan sosial. Berdasarkan teori yang ada maka teknik yang digunakan dalam penelitian sebagai upaya untuk mengembangkan keterampilan sosial adalah teknik jigsaw dan think-pair-share.

Penerapan pembelajaran kooperatif jigsaw sebagai berikut, (1) setiap anggota kelompok mempelajari atau mengerjakan salah satu bagian informasi yang berbeda dari bagian anggota lain; (2) setiap anggota kelompok bergantung kepada anggota yang lain untuk dapat mempelajari dan memahami informasi secara utuh; dan (3) setiap anggota berbagai informasi dengan anggota kelompok yang lain dalam rangka menangkap keutuhan informasi. Setiap kelompok menjadi ahli informasi sehingga kelompok akan bertanggung jawab dan menghargai masing-masing anggotanya (Rukiyah, 2012). Sedangkan penerapan model pembelajaran think-pair-share adalah sebagai berikut, (1) guru mengajukan pertanyaan dan kemudian memberikan waktu; (2) murid berbicara dengan pasangan; dan (3) murid membagikan jawaban mereka (Jolliffe, 2007).

\section{Kerangka Pemikiran}

Kerangka berpikir terkait dengan studi ini ditunjukkan dalam Gambar 1. 


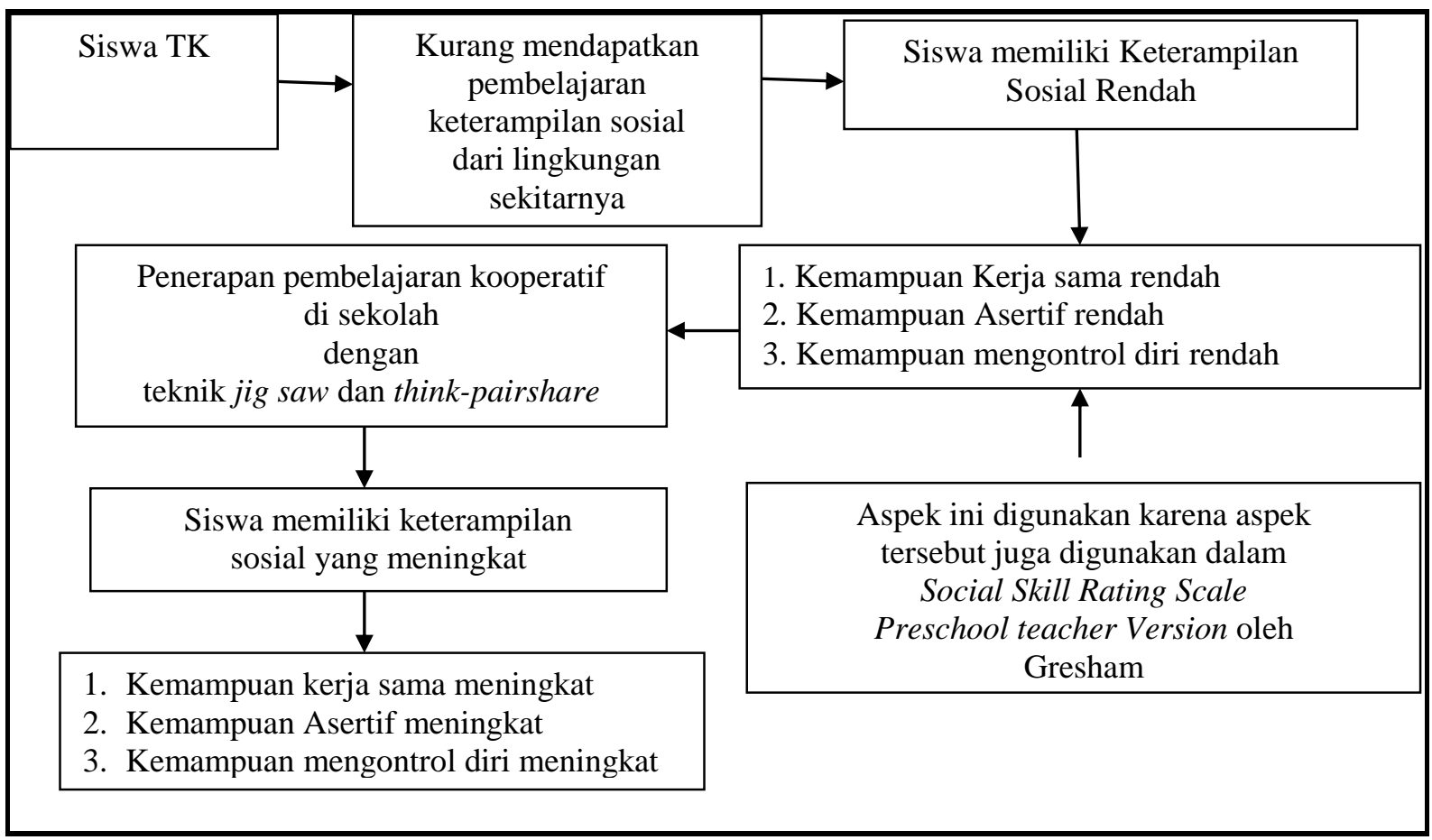

Gambar 1. Kerangka Pemikiran

\section{Tujuan Penelitian}

Tujuan penelitian ini adalah untuk melihat efektivitas penggunaan cooperative learning atau pembelajaran kooperatif untuk meningkatkan keterampilan sosial pada siswa taman kanak-kanak.

\section{Hipotesis Penelitian}

Hipotesis dalam penelitian ini adalah penggunaan pembelajaran kooperatif (cooperative learning) efektif untuk meningkatkan keterampilan sosial siswa taman kanakkanak.

\section{METODE}

\section{Partisipan}

Subjek dalam penelitian ini adalah siswa TK B Cahaya Ilmu siswa yang berada pada usia 6-7 tahun. Adapun juga siswa yang menjadi subjek penelitian memiliki keterampilan sosial yang kurang dan sedang berdasarkan hasil skala keterampilan sosial. Penentuan 
kategori subjek dengan keterampilan rendah diperoleh berdasarkan hasil skala yang diberikan pada orang tua dan guru.

\section{Desain}

Penelitian eksperimental ini dilakukan untuk mengetahui pengaruh variabel bebas terhadap variabel terikat. Dalam hal ini, peneliti menggunakan pola desain penelitian onegroup pre-test post-test design. Desain penelitian ini dapat digambarkan sebagai berikut :

$$
\text { Non Random } \mathrm{O}_{1} \longrightarrow(\mathrm{X}) \rightarrow \mathrm{O}_{2}
$$

Gambar 2. Desain Penelitian

Efektivitas atau pengaruh pemberian pembelajaran kooperatif (cooperatif learning) (X) akan dapat dilihat melalui perbedaaan hasil skor pre-test (O1) dan post-test (O2). Setiap siswa yang akan menjadi subjek akan mendapatkan pre-test dan post-test. Pre-test dan posttest dalam penelitian ini diperoleh berdasarkan lembar observasi keterampilan sosial yang dilakukan oleh asisten peneliti.

Selama proses intervensi berlangsung adapun tahapan yang digunakan dalam penelitian ini, yaitu sebagai berikut: (1) Mencari sekolah taman kanak-kanak dengan siswa pada rentang usia 5-7 tahun; (2) Melakukan observasi awal terhadap proses belajar mengajar dan keadaan siswa selama proses menerima pembelajaran dari guru; (3) Memberikan skala penilaian keterampilan sosial anak yang dilakukan oleh guru dan orangtua. Skala ini diberikan untuk melakukan penyaringan (screening) awal untuk mendapatkan subjek penelitian yang memiliki keterampilan sosial yang rendah. Dalam alat ukur ini menggunakan aspek yang sama dengan Social Skill Rating Scale Pre School Teacher And Parent Version oleh Gresham; (4) Mendaftar siswa yang akan menjadi subjek penelitian; (5) Mencari pengamat yang akan membantu penulis dalam melakukan pengamatan untuk melihat keterampilan sosial sebelum, selama, dan setelah proses pembelajaran kooperatif; (6) Memberikan modul serta memberikan penjelasan mengenai proses pembelajaran kooperatif yang akan digunakan oleh guru; (7) Melakukan observasi awal mengenai keterampilan sosial yang dimiliki subjek yang dilakukan oleh observer dengan menggunakan Lembar Pre/Post observasi keterampilan sosial; (8) Pemberian perlakukan berupa pembelajaran kooperatif pada siswa oleh guru. Dalam penelitian ini menggunakan teknik jigsaw dan think-pair-share; (9) Melakukan 
observasi selama proses intervensi dengan menggunakan lembar observasi proses pembelajaran kooperatif; (10) Penulis melakukan evaluasi hasil observasi dengan pengamat dengan menggunakan Lembar Pre/Post observasi keterampilan sosial; dan (11) Penulis melakukan analisis data penelitian.

\section{Teknik Pengumpulan Data}

Selama proses penelitian dilakukan dalam tiga tahap yaitu persiapan, pelaksanaan, dan evaluasi.

Tahap persiapan. Pada tahap persiapan dilakukan dengan cara melakukan pencarian subjek melalui guru dan orangtua. Siswa yang akan menjadi subjek adalah siswa yang memiliki keterampilan sosial rendah berdasarkan hasil skala penilaian orangtua dan guru.

Tahap pelaksanaan. Setelah subjek diperoleh guru akan mengajar seperti biasa dengan kondisi siswa telah digabung. Selama proses belajar ini pengamat akan melakukan proses observasi untuk melihat keterampilan yang dimiliki oleh subjek penelitian selama 3-5 sesi pelajaran. Selama proses observasi, penulis juga memberikan modul yang akan diterapkan selama 2 minggu ke depan atau 10 hari pelajaran.

Tahap evaluasi Proses. Selama proses pelatihan berlangsung, siswa akan diobservasi untuk melihat proses pembelajaran kooperatif. Selama observasi, pengamat juga akan melakukan observasi terhadap guru untuk melihat peran guru selama proses pelaksanaan penerapan pembelajaran kooperatif berlangsung.

\section{Teknik Analisis}

Hasil pre-test dibandingkan dengan hasil post-test yang telah dilakukan untuk mengetahui peningkatan keterampilan sosial pada siswa taman kanak-kanak menggunakan analisis data statistik. Teknik analisis data yang digunakan dalam penelitian ini adalah analisis statistik deskriptif. Teknik analisis data statistik dalam penelitian ini menggunakan teknik analisis non-parametrik dengan uji Wilcoxon dengan menggunakan SPSS 16.0.

\section{ANALISIS DAN HASIL}

Penerapan pembelajaran kooperatif teknik think-pair-share dan jigsaw efektif untuk meningkatkan keterampilan sosial pada siswa taman kanak-kanak. Pembelajaran kooperatif efektif meningkatkan semua aspek dari keterampilan siswa taman kanak-kanak yaitu aspek 
kerja sama, asertif, dan kontrol diri. Hasil statistik menunjukkan bahwa aspek kerja sama, asertif, dan kontrol diri memiliki taraf signifikasi sebesar .005.

Berdasarkan uji perbedaan dengan teknik Wilcoxon signed rank test, terlihat bahwa terdapat perbedaan antara nilai pre observasi dan post observasi. Hal ini dapat dilihat melalui nilai signifikansi yang menunjukkan .005. Dengan adanya hal tersebut dapat disimpulkan bahwa pembelajaran kooperatif efektif untuk meningkatkan keterampilan sosial ditunjukkan melalui meningkatnya keterampilan kerja sama, asertif, dan kontrol diri. Ketiga keterampilan tersebut merupakan bagian dari keterampilan sosial siswa taman kanak-kanak.

Berdasarkan uji perbedaan dengan teknik Wilcoxon signed rank test, terlihat bahwa terdapat perbedaan antara nilai sebelum dan sesudah atau pre observasi dan post observasi pada keterampilan bekerja sama subjek penelitian. Hal ini dapat dilihat melalui nilai signifikansi yang menunjukkan .005. Dengan adanya hal tersebut dapat disimpulkan bahwa pembelajaran kooperatif efektif untuk meningkatkan keterampilan bekerja sama pada siswa taman kanak-kanak. Keterampilan kerja sama yang ditunjukkan oleh siswa taman kanakkanak dalam hal ini adalah kemampuan untuk bekerja sama, membantu teman untuk menyelesaikan tugas, berbagi bahan bersama teman, melaksanakan peraturan dan perintah guru serta mau bergabung dengan anak lain.

Berdasarkan uji perbedaan dengan teknik Wilcoxon signed rank test, terlihat bahwa terdapat perbedaan antara nilai sebelum dan sesudah atau pre observasi dan post observasi pada keterampilan asertif subjek penelitian. Hal ini dapat dilihat melalui nilai signifikansi yang menunjukkan .005. Dengan adanya hal tersebut dapat disimpulkan bahwa pembelajaran kooperatif efektif untuk meningkatkan keterampilan asertif pada siswa taman kanak-kanak. Keterampilan asertif yang ditunjukkan oleh siswa taman kanak-kanak dalam hal ini adalah bertanya pada guru ketika mengalami kesulitan, mengungkapkan pendapat di depan kelas, memulai percakapan dengan anak lain, menyampaikan perasaan tidak nyaman pada guru saat di kelas dan menolak ketika diperlakukan tidak adil. Bagian keterampilan sosial terakhir yang dapat dilihat adalah keterampilan kontrol diri.

Berdasarkan uji perbedaan dengan teknik Wilcoxon signed rank test, terlihat bahwa terdapat perbedaan antara nilai sebelum dan sesudah pada keterampilan kontrol diri subjek penelitian. Hal ini dapat dilihat melalui nilai signifikansi yang menunjukkan .019. Dengan adanya hal tersebut dapat disimpulkan bahwa pembelajaran kooperatif efektif untuk meningkatkan keterampilan kontrol diri pada siswa taman kanak-kanak. Keterampilan kontrol diri yang ditunjukkan oleh siswa taman kanak-kanak dalam hal ini adalah 
mengabaikan gangguan teman saat mengerjakan tugas, berbicara baik-baik saat ada teman yang mengambil barang miliknya, menahan diri agar tidak terlibat dalam pertengkaran dengan teman saat di kelas, dan menunggu bantuan guru dengan tidak mengganggu teman.

\section{DISKUSI}

Berdasarkan hasil analisis data dengan menggunakan statistik, diperoleh kesimpulan bahwa penerapan pembelajaran kooperatif teknik think-pair-share dan jigsaw efektif untuk meningkatkan keterampilan sosial pada siswa taman kanak-kanak. Hasil penelitian yang dilakukan oleh penulis sama dengan hasil yang ditunjukkan oleh penelitian sebelumnya. Penelitian sebelumnya yang menunjukkan bahwa para peneliti telah menganjurkan pelaksanaan dan penggunaan pembelajaran kooperatif strategi jigsaw dan think-pair-share untuk dapat meningkatkan prestasi siswa dan keterampilan sosial (Dollman, dkk., 2007).

Hasil penelitian lain yang juga menunjang adalah penelitian yang dilakukan oleh Artut (2009) menunjukkan bahwa pembelajaran kooperatif efektif meningkatkan kemampuan matematika anak-anak TK perilaku sosial kooperatif anak-anak TK. Penelitian tersebut juga menggembangkan keterampilan sosial yang sederhana yaitu anak-anak harus belajar dengan mendengarkan secara aktif, senang berbicara, dan semua siswa harus menjadi peserta aktif. Menurut Elliott (dalam Frey, dkk., 2011), keterampilan sosial yang penting untuk anak-anak prasekolah meliputi mendengarkan orang lain, mengikuti peraturan kelas, mengikuti arahan, meminta bantuan, bekerja sama dengan rekan-rekan, dan mengendalikan emosi di konflik situasi. Berdasarkan perilaku di atas apabila dikelompokkan keterampilan yang dimiliki oleh siswa prasekolah masuk dalam tiga aspek yaitu kerja sama, asertif, dan kontrol diri. Berdasarkan hasil penelitian yang dilakukan oleh penulis menunjukkan bahwa pembelajaran kooperatif juga efektif meningkatkan semua aspek dari keterampilan siswa taman kanakkanak yaitu aspek kerja sama, asertif, dan kontrol diri.

\section{SIMPULAN DAN SARAN}

\section{Simpulan}

Hasil analisis data dan pembahasan penelitian yang telah dilakukan peneliti menunjukkan bahwa pembelajaran kooperatif dengan teknik think-pairshare dan jigsaw 
efektif untuk meningkatkan keterampilan sosial pada siswa taman kanak-kanak. Efektifnya metode pembelajaran kooperatif dengan teknik tersebut terlihat adanya peningkatan keterampilan sosial pada seluruh aspek yaitu kerja sama, asertif, dan kontrol diri. Peningkatan ditunjukkan melalui perbedaan hasil observasi sebelum dan sesudah adanya pembelajaran kooperatif.

\section{Saran Teoretis}

Berdasarkan hasil penelitian yang telah diperoleh, maka saran-saran yang dapat diberikan adalah sebagai berikut: (1) Peneliti selanjutnya menggunakan pembelajaran kooperatif dengan teknik jigsaw dan think-pair-share dengan menggunakan waktu lebih lama; (2) Peneliti selanjutnya diharapkan dapat mengevaluasi teknik pembelajaran kooperatif yang lebih efektif untuk siswa taman kanak-kanak jigsaw atau think-pair-share; (3) Peneliti selanjutnya dapat menggunakan pembelajaran kooperatif dengan ruang yang lebih luas dan guru pendamping yang selalu siap membantu guru fasilitator; (4) Peneliti selanjutnya dapat memberikan pelatihan pada guru tentang pembelajaran kooperatif dengan menggunakan role play yang sesungguhnya sehingga dapat lebih memberikan detail peran guru mengenai pembagian tugas terhadap siswa saat melakukan kegiatan berkelompok; dan (5) Peneliti berikutnya dapat memberikan peraturan yang lebih konkrit dengan menggunakan media gambar selama pembelajaran kooperatif berlangsung.

\section{Saran Praktis}

Berdasarkan hasil penelitian yang telah diperoleh, maka saran-saran yang dapat diberikan adalah sebagai berikut.

Saran yang dapat diberikan untuk guru dan pihak sekolah adalah: (1) Pihak sekolah perlu memasukkan proses pengenalan keterampilan sosial; (2) Secara lebih terstruktur dalam pembelajaran di kelas pada siswa sehingga perilaku negatif siswa dapat lebih ditekan; (3) Guru dapat menggunakan pembelajaran kooperatif sebagai variasi metode pembelajaran di kelas sehingga keterampilan sosial siswa dapat lebih berkembang; (4) Guru diharapkan dapat melanjutkan pembelajaran yang pernah dilakukan oleh peneliti dengan setting kelompok yang berbeda. Hal ini dilakukan agar siswa juga dapat bekerja sama dengan anak lain saat di kelas; (5) Guru dapat menerapkan pembelajaran kooperatif pada seluruh aspek pembelajaran baik kognitif, fisik motorik maupun sosial pada siswa taman kanak-kanak; dan (6) Guru dapat 
membina komunikasi dengan orangtua agar mau mengajarkan anak keterampilan sosial saat di rumah.

\section{REFERENSI}

Artut, P. D. (2009). Experimental evaluation of the effects of cooperative learning on kindergarten children's mathematics ability. International journal of educational research, 48, 370-380.

Departemen Pendidikan dan Kebudayaan. (2003). Naskah akademik kajian kebijakan kurikulum pendidikan anak usia dini. Jakarta, Indonesia: Badan Penelitian dan Pengembangan Pusat Kurikulum.

Departemen Pendidikan dan Kebudayaan. (2004). Kurikulum TK dan RA standar kompetensi. Jakarta, Indonesia: Badan Penelitian dan Pengembangan Pusat Kurikulum.

Dollman, L., Morgan, C., Pergler, J., Russell, W., \& Watt, J. (2007). Improving social skill through the use of cooperative learning (Proyek penelitian tidak dipublikasikan). Saint Xavier University, Amerika Serikat.

Elliot, S, N., \& Busse, R. T. (1991). Social skills assessment and intervention with children and adolescents. School Psychology International, 12(1/2), 63-83.

Frey, J. R., Elliot, S. N., \& Gresham, F. M. (2011). Preschoolers' social skills: Advances in assessment for intervention using social behavior ratings. School Mental Health, 3, 179.

Gillies, M. R., \& Ashman, F. A. (2003). Co-operative learning: The social and intellectual outcomes of learning in groups. London: RoutledgeFalmer.

Gresham, F. M. (1981). Assesment of children's social skill. Journal School Psychology, 19(2), 120-133.

Izzaty, R. I., Cholimah, N., \& Hayati, N. (n.d.). Pelatihan Penggunaan Buku Panduan Keterampilan Sosial Bagi Pendidikan PAUD Non Formal TPA/KB Se-Kecamatan Sleman. Ditemu kembali di http://staff.uny.ac.id/sites/default/files/pengabdian/ nurcholimah-spd-mpd/artikel-ppm-reguler-ketrampilan-sos-2.pdf

Jennings, L. J., \& Diprete. A. T. (2009). Teacher effects on social/behavioral skills in early elementary school. New York, NY: Columbia University.

Jolliffe, W. (2007). Cooperative learning in the classroom putting it into practice. London: Sage. 
Kibtiyah, M. (2003). Efektivitas cooperatif games dalam meningkatkan keterampilan sosial anak TK (Tesis tidak dipublikasikan). Universitas Gadjah Mada, Indonesia.

Mukhtar, Y. D., \& Hadhan, R. N. (2006). Efektivitas art therapy untuk meningkatkan keterampilan sosial pada anak yang mengalami gangguan perilaku. Psikologia, 2(1), $16-24$.

Pujiani, Soedirman, O., \& Purnomoso, W., (2011). Hubungan pola pengasuhan ibu dengan keterampilan sosial anak usia 6 tahun di TK ABA kabupaten Jombang. Sain Med Jurnal Kesehatan, 4(1), 52-53

Rukiyah. (2012). Pembelajaran IPA di SD melalui penerapan model kooperatif teknik jigsaw. Paedagogia Jurnal Penelitian Pendidikan, 15(1), 45-54.

Setiawati, F. A. (n.d). Pengembangan buku panduan model program pembelajararan keterampilan sosial anak bagi pendidik taman kanak-kanak. Ditemu kembali dari http://staff.uny.ac.id/sites/default /files/Artikel Penelit sranas final.pdf 